\title{
Airborne cultivable microflora and microbial transfer in farm buildings and rural dwellings
}

\author{
Anne-Cécile Normand, ${ }^{1}$ Bertrand Sudre, ${ }^{2}$ Mallory Vacheyrou, ${ }^{2}$ Martin Depner, ${ }^{3}$ \\ Inge M Wouters, ${ }^{4}$ Ilka Noss, ${ }^{4}$ Dick Heederik, ${ }^{4}$ Anne Hyvärinen, ${ }^{5}$ Jon Genuneit, ${ }^{6}$ \\ Charlotte Braun-Fahrländer, ${ }^{7}$ Erika von Mutius, ${ }^{3}$ Renaud Piarroux, ${ }^{1}$ the GABRIEL-A \\ Study Group
}

${ }^{1}$ Department of Parasitology and Mycology, Assistance

Publique-Hôpitaux de Marseille, Marseille, France

2Franche-Comté University, UMR-CNRS 6249

Chrono-Environnement,

Mycology Department,

Besançon, France

${ }^{3}$ Children's Hospital of the

University of Munich,

Lindwurmstrasse 4, Munich,

Germany

${ }^{4}$ Institute for Risk Assessment

Sciences, Division of

Environmental Epidemiology,

Utrecht University, TD Utrecht,

The Netherlands

${ }^{5}$ National Institute for Health and Welfare, Department of

Environmental Health, Kuopio,

Finland

${ }^{6}$ Institute of Epidemiology,

University of Ulm, Ulm, Germany

${ }^{7}$ Swiss Tropical and Public

Health Institute, Basel,

Switzerland

\section{Correspondence to}

Anne-Cécile Normand, Laboratoire de

Parasitologie/Mycologie, Hôpital de la Timone, 264 rue Saint-Pierre, 13385 Marseille cedex 05, France; acecilenor@hotmail.com

The GABRIEL-A Study Group consists of the following members of GABRIEL-A study centres: Austria: Katalin Kovacs, Bernhard Morass, Elisabeth Horak; Baden-Württemberg (Germany): Gisela Büchele, Nikolaos Sitaridis, Jon Genuneit; Bavaria (Germany): Juliane Weber, Erika von Mutius: Poland: Anna Debinska, Hanna Danielewicz, Barbara Sozanska; Switzerland: Marco Waser, Charlotte Braun-Fahrländer

Accepted 2 March 2011 Published Online First 24 March 2011

\section{ABSTRACT}

Objectives Exposure to environments rich in

microorganisms such as farms has been shown to protect against the development of childhood asthma and allergies. However, it remains unclear where, and how, farm and other rural children are exposed to microbes. Furthermore, the composition of the microbial flora is poorly characterised. We tested the hypothesis that farm children are exposed indoors to substantial levels of viable microbes originating from animal sheds and barns. We also expected that environmental microbial flora on farms and in farm homes would be more complex than in the homes of rural control children. Methods Dust samples were collected using passive samplers in the bedrooms of the following groups of children in rural Bavaria, Germany: (i) those living on farms ( $n=144$ ), (ii) those regularly exposed to farm environments but not living on farms $(n=149)$ and (iii) those never visiting farms $(n=150)$. For farm children, additional samples were collected in animal sheds and barns. All samples were subjected to fungal and bacterial culturing.

Results Detectable levels of microorganisms were more often found in samples taken from farm dwellings than from other homes. Farm dwellings also showed higher microbial levels. Microbial counts of farm dwelling samples correlated with the counts in corresponding animal sheds and barns.

Conclusions Microorganisms are transported from animal sheds and barns into farm dwellings. Therefore, children living in these environments are exposed when indoors and when visiting animal sheds and barns. Indoor exposure may also contribute to the protective effect of the farm environment.

\section{INTRODUCTION}

Exposure to environments rich in microorganisms such as farms has previously been shown to protect against the development of childhood asthma and allergies. ${ }^{1-7}$ In particular, frequent contact with farm animals during early childhood seems to be an important determining factor. In farm dwellings, environmental studies have shown increased levels of microbe associated molecular patterns such as endotoxin from Gram-negative bacteria, muramic acid from Gram-positive bacteria, and $\beta(1-3)-D-$ glucans and extracellular polysaccharides from fungi, as compared to rural non-farm dwellings.

\section{What this paper adds}

The farm environment has been shown to offer protection against asthma and allergies in children.

- The role of microorganisms has been recognised, but the microbial flora to which farm children are exposed is poorly characterised.

- This study shows that children living on farms are exposed to many microorganisms and that numerous fungal and bacterial taxa found in farm dwellings are also found in animal sheds and barns.

- Fewer microorganisms are found in the rural dwellings of non-farmers.

However, little is known about the complex microbial flora which underlies exposure to these microbial markers. We hypothesised that children were exposed to substantial levels of viable microbes not only in animal sheds and barns, but also indoors in the farm dwelling. We also hypothesised that the indoor levels and spectra of microorganisms were determined by the microorganisms present in animal sheds and barns.

Air in animal sheds is highly contaminated with numerous species of moulds and bacteria, including high levels of actinomycetes. ${ }^{8-11}$ Individuals working on a farm may transport microorganisms from the animal shed to the dwelling. ${ }^{12}{ }^{13}$ However, the microbial flora to which farm children may be exposed is poorly characterised.

The objectives of the present study were therefore to determine whether the microbes children were exposed to indoors in farm environments originated from animal sheds and barns, and to measure the levels of fungi and bacteria in farm and control rural dwellings. We therefore studied: (i) the microbial flora in the dwellings (bedrooms) of three groups of children living in a rural environment in the German Alpine region: one group living on farms, one group occasionally exposed to farm environments, and one group with no exposure to a farm environment; (ii) the microbial flora collected in the animal sheds and barns of farm dwellings; and (iii) the relationship between the 
level of contamination in the farm dwelling and in associated animal sheds and barns.

This project is part of the GABRIEL Advanced Studies, which were designed to identify environmental microbial exposures in farm environments and determine the exposures protecting against the development of asthma and allergic diseases.

\section{MATERIALS AND METHODS}

\section{Study design}

This environmental study is nested in phase III of the GABRIEL Advanced Studies (figure 1). The farms included in this study were mixed traditional family farms, with mainly cows and some small animals such as chickens; some farms had modest numbers of pigs. Crops produced were often grown as animal feed. ${ }^{14}$ Three non-overlapping strata were defined: (i) farm children, that is children living on a farm run by their family at the time of assessment; (ii) exposed non-farm children, that is non-farm children regularly visiting animal sheds, barns or consuming cows milk produced on a farm; and (iii) non-exposed rural non-farm children. From the children participating in all phase II study modules, a stratified random sample of 895 subjects using nine dwelling strata (three for health status (those with asthma, those with atopy and controls) and three for the exposure (non-exposed children, exposed children and farm children)) was invited to participate in phase III in which we performed in-depth environmental sampling. For the nested study presented here, 444 subjects from phase III were selected (approximately 50 subjects per stratum) and data were obtained for 443. For farm children, sampling involved dwellings and associated barns and animal sheds.

\section{Airborne dust samples}

Airborne dust samples were collected by a passive collection method using electrostatic dust fall collectors (EDCs). Details about the use of EDCs in indoor and animal shed environments have been described elsewhere as well as the results of validation pilot studies. ${ }^{15} 16$ Briefly, EDCs are plastic sample holders equipped with between two and four electrostatic cloths with a cloth exposure area of $0.0209 \mathrm{~m}^{2}$ (Zeeman, Utrecht, The Netherlands). When exposed to air, EDCs capture settling dust due to their electrostatic properties. EDCs have been validated against active dust $\mathrm{PM}_{10}$ sampling methods such as the Harvard impactor. ${ }^{16}$ Within each dwelling, one EDC was placed in the child's bedroom and also, if applicable, in whichever barn and/or animal shed in which the child spent most of his or her time, resulting in the collection of 150 EDCs from the non-exposed
Figure 1 Flow chart of the GABRIEL Advanced Studies in Bavaria, Germany. Samples from 443 dwellings (bedrooms) were included in the current analyses from among the 895 children invited for in-depth exposure assessment within phase III of the GABRIEL Advanced Studies. For all participants, dust was collected in the child's room. For farm children, dust was additionally collected on the farm or the animal shed wherever possible. EDC, electrostatic dust fall collector.

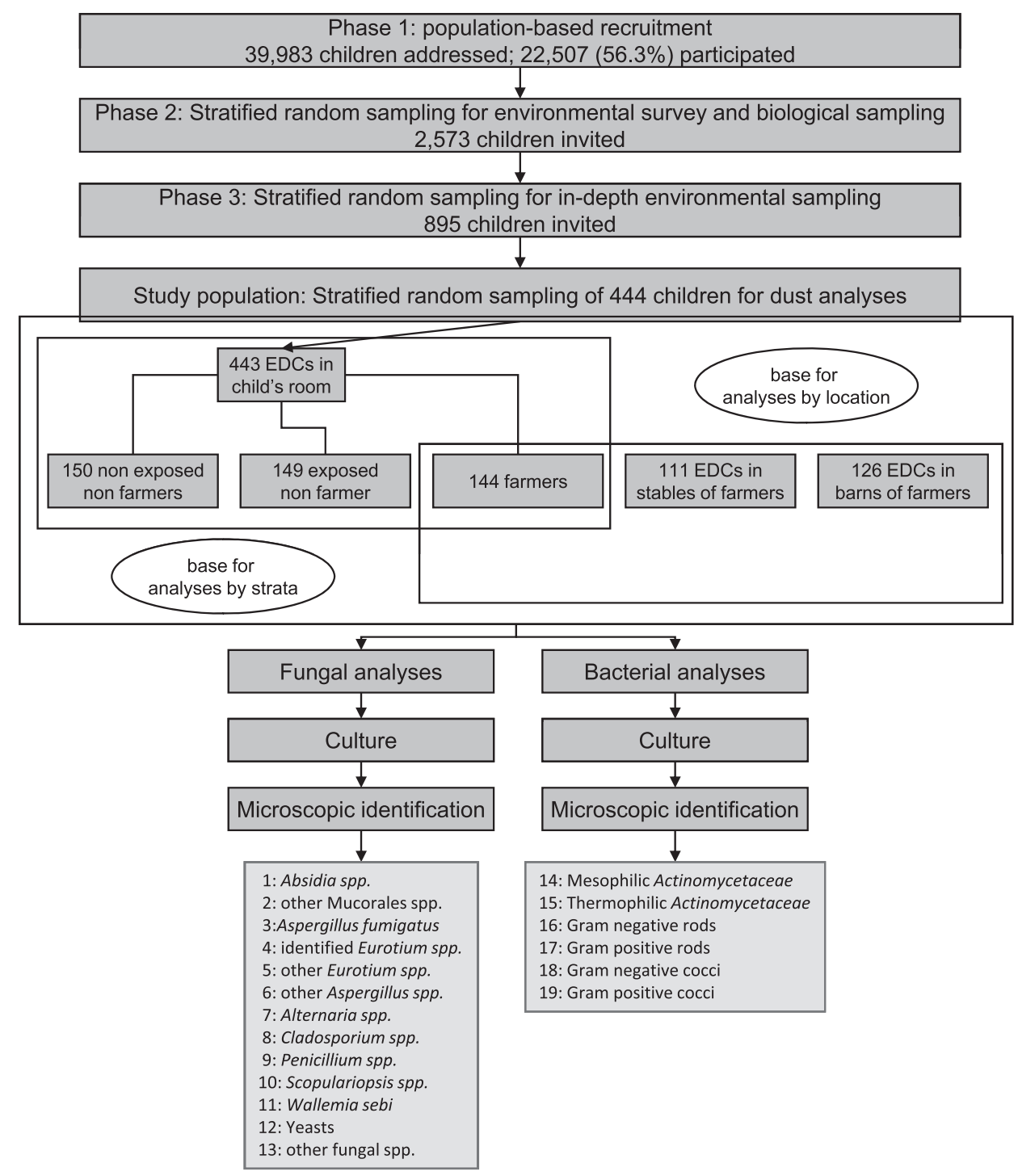


children's bedrooms, 149 from exposed children's bedrooms, 144 from farm children's bedrooms, 111 from animal sheds and 126 from barns. EDCs were placed by a fieldwork team member. After exposure to air for 14 days, the families were asked to close the EDCs and returned them to the study centre in Munich by post, after which they were sent to Utrecht for further processing. The four electrostatic cloths were transferred individually into plastic bags and stored frozen: three cloths were stored at $-80^{\circ} \mathrm{C}$ and one cloth was stored at $-20^{\circ} \mathrm{C}$. Samples stored at $-20^{\circ} \mathrm{C}$ were used for the analyses described in this manuscript and were sent to the microbiology laboratory in Besançon, France, to be analysed for microbial composition within 4-8 months. Sampling was performed during the 2007-2008 winter, as high humidity levels were conducive to the development of fungi. A total of 680 EDCs were available for analyses.

\section{Treatment of EDC cloths for microbiological analyses}

Microbiological analyses were performed blindly, with the operators unaware of the characteristics of each sample. The cloths were put in a sterile bag with $20 \mathrm{ml}$ of $0.1 \%$ Tween 80 and shaken for $10 \mathrm{~min}$ in a Stomacher (AES Laboratoire, Combourg, France). Samples of the washing solution were added to different growth media suitable for a range of microorganisms, and the analyses were performed as described below.

\section{Culturing}

Aliquots $(100 \mu \mathrm{l})$ of the cloth washing solution were spread on five different agars: (i) Dichloran-Glycerol 18 (Oxoid, Basingstoke, England) with $0.5 \%$ chloramphenicol (Sigma-Aldrich, Steinheim, Germany) incubated at $30^{\circ} \mathrm{C}$ for mesophilic mould isolation, (ii) 3\% malt-agar (AES, Bruz, France) with 10\% salt and $0.5 \%$ chloramphenicol, incubated at room temperature for osmophilic fungal species, (iii) Difco actinomycetes isolation agar (Becton Dickinson, Le Pont de Claix, France) incubated at $30^{\circ} \mathrm{C}$ for mesophilic actinomycetes, (iv) R8 medium incubated at $52^{\circ} \mathrm{C}$ for thermophilic actinomycetes, ${ }^{17}$ and (v) CHROMagar Orientation (CHROMagar, Paris, France) incubated at room temperature for bacterial growth and phenotypic differentiation. Because the different samples were blindly analysed and microbial contamination levels were unknown, four dilutions (pure, 10, 100 and 1000-fold dilutions) were used for the analysis of bacteria on the CHROMagar Orientation medium. For fungi and actinomycetes, three dilutions (pure, 10 and 100-fold dilutions) were systematically plated for counting and identification purposes. Microbial counts were then performed on those plates with the more concentrated inoculums that had sufficient colonies.

\section{Fungal identification}

After 7 days of incubation, the colonies were counted and identified using macroscopic and microscopic criteria, following the keys in the Atlas of Clinical Fungi. ${ }^{18}$ Slow-growing fungi were identified 14 days after incubation, using the same methods. Forty-four fungal species were identified, and taxa were built for use in further medical analyses. We particularly focused on genera and species commonly found in the farm environment and suspected of provoking allergic or pulmonary diseases among farmers, namely Absidia spp. (farmer's lung diseases), Alternaria spp. (allergy), Aspergillus spp. and more particularly Aspergillus fumigatus (asthma) and Aspergillus glaucus (farmer's lung diseases), Cladosporium spp. (allergy), Penicillium spp. (farmer's lung diseases and allergy), Scopulariopsis sp. (allergy) and Wallemia sebi (farmer's lung diseases). ${ }^{11}{ }^{19} 20$ Other fungi were classified into yeasts, other Mucorales species and unidentified moulds.

Table 1 Number and frequency of detected microorganisms, stratified according to exposure strata and location on the farm

\begin{tabular}{|c|c|c|c|c|c|c|c|c|c|c|c|c|}
\hline & \multicolumn{2}{|c|}{$\begin{array}{l}\text { Non- } \\
\text { exposed } \\
\text { non-farm } \\
\text { children } \\
\text { dwellings } \\
\mathrm{N}=150\end{array}$} & \multicolumn{2}{|c|}{$\begin{array}{l}\text { Exposed } \\
\text { non-farm } \\
\text { children } \\
\text { dwellings }\end{array}$} & \multicolumn{2}{|c|}{$\begin{array}{l}\begin{array}{l}\text { Farm } \\
\text { children } \\
\text { dwellings }\end{array} \\
\mathrm{N}=144\end{array}$} & \multicolumn{2}{|c|}{$\begin{array}{l}\begin{array}{l}\text { Animal } \\
\text { sheds }\end{array} \\
N=111\end{array}$} & \multicolumn{2}{|c|}{$\frac{\text { Barns }}{\mathrm{N}=126}$} & \multirow{2}{*}{$\begin{array}{l}\text { Farm vs } \\
\text { non-exposed non-farm } \\
\text { children dwellings } \\
\chi^{2}\end{array}$} & \multirow{2}{*}{$\begin{array}{l}\text { Farm vs exposed } \\
\text { non-farm children } \\
\text { dwellings } \\
\chi^{2}\end{array}$} \\
\hline & $\mathbf{N}$ & $\%$ & $\overline{\mathbf{N}}$ & $\%$ & $\overline{\mathbf{N}}$ & $\%$ & $\overline{\mathbf{N}}$ & $\%$ & $\overline{\mathbf{N}}$ & $\%$ & & \\
\hline Absidia spp. & 5 & 3.3 & 7 & 4.7 & 35 & 24.3 & 61 & 55.0 & 67 & 53.2 & $27.5^{* * *}$ & $22.9 * * *$ \\
\hline Other Mucorales spp. & 12 & 8.0 & 11 & 7.4 & 31 & 21.5 & 48 & 43.2 & 45 & 35.7 & $10.8^{* *}$ & $11.9 * *$ \\
\hline Aspergillus fumigatus & 32 & 21.3 & 40 & 26.9 & 55 & 38.2 & 74 & 66.7 & 88 & 69.8 & $10.0^{* *}$ & $4.3^{*}$ \\
\hline Identified Eurotium spp.† & 27 & 18.0 & 40 & 26.9 & 95 & 66.0 & 72 & 64.9 & 75 & 59.5 & $69.6^{* * *}$ & $45.1^{* * *}$ \\
\hline Other Eurotium spp. & 21 & 14.0 & 22 & 14.8 & 51 & 35.4 & 51 & 46.0 & 53 & 42.1 & $18.2^{* * *}$ & $16.7^{* * *}$ \\
\hline Other Aspergillus spp. & 57 & 38.0 & 66 & 44.3 & 95 & 66.0 & 75 & 67.6 & 87 & 69.1 & $23.0 * * *$ & $13.9 * * *$ \\
\hline Alternaria spp. & 8 & 5.3 & 11 & 7.4 & 19 & 13.2 & 35 & 31.5 & 44 & 34.9 & $5.4^{*}$ & 2.7 (NS) \\
\hline Cladosporium spp. & 77 & 51.3 & 73 & 49.0 & 116 & 80.6 & 82 & 73.9 & 104 & 82.5 & $27.8^{* * *}$ & $31.9 * * *$ \\
\hline Penicillium spp. & 113 & 75.3 & 113 & 75.8 & 127 & 88.2 & 80 & 72.1 & 73 & 57.9 & $8.1^{* *}$ & $7.5^{* *}$ \\
\hline Scopulariopsis sp. & 5 & 3.3 & 10 & 6.7 & 41 & 28.5 & 66 & 59.5 & 69 & 54.8 & $35.2^{* * *}$ & $24.1 * * *$ \\
\hline Wallemia sebi & 18 & 12.0 & 27 & 18.1 & 69 & 47.9 & 50 & 45.1 & 78 & 61.9 & $45.5^{* * *}$ & $29.5^{* * *}$ \\
\hline Yeast & 12 & 8.0 & 19 & 12.8 & 44 & 30.6 & 72 & 64.9 & 48 & 38.1 & $24.2^{* * *}$ & $13.8^{* * *}$ \\
\hline Other fungi & 44 & 29.3 & 46 & 30.9 & 66 & 45.8 & 72 & 64.9 & 78 & 61.9 & $8.5^{* *}$ & $6.9 * *$ \\
\hline Mesophilic Actinomycetaceae & 38 & 25.3 & 45 & 30.2 & 111 & 77.1 & 109 & 98.2 & 117 & 92.9 & $78.7^{* * *}$ & $64.7^{* * *}$ \\
\hline Thermophilic Actinomycetaceae & 8 & 5.3 & 27 & 18.1 & 45 & 31.3 & 79 & 71.2 & 71 & 56.4 & $33.4^{* * *}$ & $6.8^{* *}$ \\
\hline Gram negative rods & 79 & 52.7 & 87 & 58.4 & 121 & 84.0 & 95 & 85.6 & 112 & 88.9 & $33.2^{* * *}$ & $23.4^{* * *}$ \\
\hline Gram positive rods & 89 & 59.3 & 91 & 61.1 & 132 & 91.7 & 90 & 81.1 & 111 & 88.1 & $41.2^{* * *}$ & $37.7^{* * *}$ \\
\hline Gram negative cocci & 41 & 27.3 & 44 & 29.5 & 67 & 46.5 & 38 & 34.2 & 30 & 23.8 & $11.6^{* *}$ & $9.0^{* *}$ \\
\hline Gram positive cocci & 106 & 70.7 & 95 & 63.8 & 133 & 92.4 & 94 & 84.7 & 109 & 86.5 & $22.7^{* * *}$ & $34.7^{* * *}$ \\
\hline
\end{tabular}

$\chi^{2}$ Test statistics representing differences in frequencies between exposure strata (farm vs exposed and farm vs non-exposed) are given.

${ }^{*} \mathrm{p}<0.05 ;{ }^{* *} \mathrm{p}<0.001 ;{ }^{* * *} \mathrm{p}<0.0001$.

†Identified Eurotium spp. and their teleomorphs: Aspergillus hollandicus, Aspergillus glaucus, Eurotium amstelodami and Eurotium herbarorium.

$\mathrm{N}$, number of positive samples; NS, non-significant. 


\section{Bacterial identification}

Bacterial colonies were selected from CHROMagar Orientation medium according to colony morphotype, subjected to Gram staining and classified. We classified and counted the actinomycetes cultured on Difco and R8 media according to growth temperature. We presented results of fungal identification according to bacterial taxa. We particularly focused on actinomycetes counts because these bacteria are known to be present in high amounts in the farm environment and to be responsible for immuno-allergic diseases such as farmer's lung disease. ${ }^{11} 19$ Identification of each bacterial colony at the genus or species level will be continued in a further project on bacterial environmental characterisation as a specimen of every colony was re-isolated by sub-culturing and frozen at $-80^{\circ} \mathrm{C}$ for analyses. Bacterial and fungal results were expressed in colony forming units (CFU) per plate and further converted to CFU per EDC and $\mathrm{CFU} / \mathrm{m}^{2}$ taking into account the dilution steps and the exposure surface area of the EDC $\left(0.0209 \mathrm{~m}^{2}\right)$.

\section{Statistical analyses}

Due to the procedure used, levels below 200 CFU/EDC could not be detected. For calculation of the arithmetical mean, zero values were kept as such. For calculation of the geometric mean, nondetects were replaced by half of the limit of detection $(1 / 2 \times 200 /$ $\left.0.0209 \mathrm{CFU} / \mathrm{m}^{2}=4784.69 \mathrm{CFU} / \mathrm{m}^{2}\right)$. The geometric means and $95 \%$ CIs of each microbial category stratified by exposure (nonexposed non-farm children, exposed non-farm children, farm children) and farm location (farm dwelling, animal shed, barn) were calculated. To test for differences in the frequencies of detectable microorganisms between exposure strata, a Pearson's $\chi^{2}$ test was used. Spearman's $r$ was used to calculate correlations between the corresponding viable microorganisms in dwellings and barns ( $\mathrm{n}=125$ matched pairs) and between dwellings and animal sheds ( $n=110$ matched pairs). Statistical significance was set at the 5\% level. STATA 10 SE was used for statistical analyses.

\section{RESULTS}

Numerous fungal and bacterial taxa were detected from the 680 analysed EDCs. However, only one fungal and three bacterial taxa, that is Penicillium spp., Gram negative rods, Gram positive rods and Gram positive cocci, were found in more than $50 \%$ of samples collected in the different environments (non-exposed dwelling, exposed dwelling, farm dwelling, animal shed and barn). There was a marked trend towards a higher proportion of samples with detectable levels of microorganisms by taxa collected from the dwellings of the farm children than from the dwellings of the non-exposed and exposed children (table 1).

In particular, the proportion of positive samples for each bacterial and fungal taxon was significantly higher in farm dwellings than in exposed or non-exposed dwellings. There was a trend for a higher proportion of detectable fungi and bacteria in exposed dwellings compared to non-exposed dwellings, but the difference was only significant for the thermophilic Actinomycetaceae group (data not shown).

The higher exposure in farm dwellings was evidenced by the proportion of detectable samples and by increased concentrations. As shown in table 2, the geometric mean concentration of detectable samples for every microbial parameter was higher in farm dwellings than in the two other types of dwellings, with the exception of Scopulariopsis sp. Moreover, for most taxa, the

Table 2 Geometric means and GSDs of microorganisms (in $\mathrm{CFU} / \mathrm{m}^{2}$ ) by exposure strata and by location on the farm, and Spearman correlation coefficients between microorganism levels in the farm dwelling and in the animal shed or barn

\begin{tabular}{|c|c|c|c|c|c|c|c|c|c|c|c|c|c|c|}
\hline & \multicolumn{2}{|c|}{$\begin{array}{l}\text { Non- } \\
\text { exposed } \\
\text { non-farm } \\
\text { dwelling }\end{array}$} & \multicolumn{2}{|c|}{$\begin{array}{l}\text { Exposed } \\
\text { non-farm } \\
\text { dwelling }\end{array}$} & \multicolumn{2}{|c|}{$\begin{array}{l}\text { Farm } \\
\text { dwelling }\end{array}$} & \multicolumn{2}{|c|}{ Animal shed } & \multicolumn{2}{|l|}{ Barn } & \multicolumn{2}{|c|}{$\begin{array}{l}\text { Farm dwelling/animal } \\
\text { shed }(n=110)\end{array}$} & \multicolumn{2}{|c|}{$\begin{array}{l}\text { Farm dwelling/barn } \\
(n=125)\end{array}$} \\
\hline & $\begin{array}{l}\mathrm{GM} / \\
1000\end{array}$ & GSD & $\begin{array}{l}\mathrm{GM} / \\
1000\end{array}$ & GSD & $\begin{array}{l}\text { GM/ } \\
1000\end{array}$ & GSD & $\begin{array}{l}\text { GM/ } \\
1000\end{array}$ & GSD & $\begin{array}{l}\mathrm{GM} / \\
1000\end{array}$ & GSD & Spearman's r & p Value & Spearman's r & p Value \\
\hline Absidia spp. & 5 & 0.1 & 5 & 0.1 & 9 & 1.6 & 48 & 5.7 & 38 & 6.5 & 0 & $* * *$ & 0 & $* * *$ \\
\hline Other Mucorales spp. & 5 & 0.1 & 5 & 0.3 & 7 & 0.9 & 19 & 3.4 & 15 & 3.6 & 0 & NS & 0 & * \\
\hline Aspergillus fumigatus & 6 & 0.6 & 8 & 1.2 & 10 & 1.9 & 55 & 4.1 & 34 & 6.0 & 0 & $* * *$ & 0 & $* * *$ \\
\hline Identified Eurotium spp. $\dagger$ & 6 & 0.6 & 7 & 0.8 & 23 & 2.6 & 187 & 8.7 & 110 & 9.8 & 0 & $* * *$ & 0 & $* * *$ \\
\hline Other Eurotium spp. & 6 & 0.4 & 6 & 0.5 & 11 & 1.7 & 69 & 7.3 & 39 & 9.5 & 0 & $* * *$ & 0 & NS \\
\hline Other Aspergillus spp. & 9 & 1.2 & 10 & 1.4 & 20 & 2.1 & 131 & 5.7 & 78 & 7.6 & 0 & $* * *$ & 0 & $* * *$ \\
\hline Alternaria spp. & 5 & 0.1 & 5 & 0.1 & 6 & 0.3 & 11 & 2.2 & 12 & 2.5 & 0 & * & 0 & NS \\
\hline Cladosporium spp. & 10 & 1.1 & 9 & 0.8 & 23 & 1.6 & 189 & 5.7 & 316 & 6.4 & 0 & * & 0 & NS \\
\hline Penicillium spp. & 22 & 1.8 & 28 & 2.1 & 48 & 2.0 & 122 & 5.6 & 57 & 5.3 & 0 & * & 0 & $*$ \\
\hline Scopulariopsis sp. & 5 & 0.0 & 6 & 0.4 & 7 & 0.8 & 59 & 4.3 & 30 & 6.6 & 0.26 & $* *$ & 0.28 & $* *$ \\
\hline Wallemia sebi & 6 & 0.3 & 7 & 0.8 & 14 & 2.0 & 51 & 7.6 & 108 & 8.1 & 0 & ** & 0 & $* *$ \\
\hline Yeast & 5 & 0.1 & 6 & 0.4 & 10 & 1.7 & 126 & 7.2 & 34 & 7.5 & 0 & $*$ & 0 & $*$ \\
\hline Other fungi & 8 & 0.8 & 8 & 0.9 & 11 & 1.6 & 77 & 5.9 & 67 & 5.8 & 0 & $*$ & 0 & NS \\
\hline Mesophilic Actinomycetaceae & 6 & 0.4 & 7 & 0.8 & 41 & 3.4 & 1682 & 5.3 & 477 & 4.1 & 0 & $* * *$ & 0 & $* * *$ \\
\hline Thermophilic Actinomycetaceae & 5 & 0.1 & 6 & 0.5 & 9 & 1.7 & 71 & 4.8 & 30 & 5.7 & 0 & $* * *$ & 0 & $*$ \\
\hline Gram negative rods & 15 & 2.0 & 17 & 2.7 & 122 & 5.2 & 7022 & 8.6 & 2258 & 12.3 & 0 & $* *$ & 0 & $* * *$ \\
\hline Gram positive rods & 13 & 1.4 & 17 & 2.9 & 246 & 5.3 & 5604 & 9.3 & 2792 & 15.6 & 0 & $* *$ & 0 & $* * *$ \\
\hline Gram negative cocci & 9 & 1.5 & 9 & 1.8 & 21 & 4.9 & 68 & 4.6 & 15 & 14.5 & 0 & NS & 0 & NS \\
\hline Gram positive cocci & 27 & 3.7 & 29 & 4.7 & 454 & 6.0 & 25368 & 10.0 & 1841 & 16.6 & 0 & $* * *$ & 0 & $* * *$ \\
\hline
\end{tabular}

${ }^{*} \mathrm{p}<0.05 ;{ }^{* *} \mathrm{p}<0.001 ;{ }^{* * *} \mathrm{p}<0.0001$.

†ldentified Eurotium spp. and their teleomorphs: Aspergillus hollandicus, Aspergillus glaucus, Eurotium amstelodami and Eurotium herbarorium.

Mean values are expressed in colony forming unit per square metre (CFU $\left./ \mathrm{m}^{2}\right)$. Non-detects have been replaced by half of the limit of detection for $\mathrm{GM}$ calculations.

Spearman's $r$ is shown for farm children for whom electrostatic dust fall collectors from either farm source were returned: child's room and animal shed ( $N=110$ ) or child's room and barn $(\mathrm{N}=125)$.

GM, geometric mean; GSD, geometric SD; NS, non-significant. 
Table 3 Number of samples with or without specified microorganisms identified in farm dwellings and/or other indoor farm source (animal shed or barn)

\begin{tabular}{|c|c|c|c|c|c|c|}
\hline & \multicolumn{4}{|c|}{ Present in farm dwelling/animal shed or barn } & \multirow{2}{*}{$\begin{array}{l}\text { Proportion of }+/+ \text { of } \\
\text { all farm dwelling positives }\end{array}$} & \multirow{2}{*}{$\begin{array}{l}\text { Proportion of }-/+ \text { of } \\
\text { all farm dwelling negatives }\end{array}$} \\
\hline & $-1-$ & $+/-$ & $-/+$ & $+/+$ & & \\
\hline Absidia spp. & 30 & 0 & 39 & 29 & $100 \%$ & $57 \%$ \\
\hline Other Mucorales spp. & 36 & 8 & 39 & 15 & $65 \%$ & $52 \%$ \\
\hline Aspergillus fumigatus & 16 & 3 & 46 & 33 & $92 \%$ & $74 \%$ \\
\hline Identified Eurotium spp.* & 8 & 9 & 26 & 55 & $86 \%$ & $76 \%$ \\
\hline Other Eurotium spp. & 25 & 8 & 40 & 25 & $76 \%$ & $62 \%$ \\
\hline Other Aspergillus spp. & 8 & 7 & 26 & 57 & $89 \%$ & $76 \%$ \\
\hline Alternaria spp. & 42 & 3 & 45 & 8 & $73 \%$ & $52 \%$ \\
\hline Cladosporium spp. & 0 & 4 & 19 & 75 & $95 \%$ & $100 \%$ \\
\hline Penicillium spp. & 1 & 12 & 10 & 75 & $86 \%$ & $91 \%$ \\
\hline Scopulariopsis sp. & 19 & 5 & 49 & 25 & $83 \%$ & $72 \%$ \\
\hline Wallemia sebi & 16 & 8 & 37 & 37 & $82 \%$ & $70 \%$ \\
\hline Yeast & 24 & 0 & 42 & 32 & $100 \%$ & $64 \%$ \\
\hline Other fungi & 11 & 5 & 40 & 42 & $89 \%$ & $78 \%$ \\
\hline Mesophilic Actinomycetaceae & 0 & 0 & 17 & 81 & $100 \%$ & $100 \%$ \\
\hline Thermophilic Actinomycetaceae & 11 & 2 & 52 & 33 & $94 \%$ & $83 \%$ \\
\hline Gram negative rods & 0 & 1 & 17 & 80 & $99 \%$ & $100 \%$ \\
\hline Gram positive rods & 2 & 3 & 8 & 85 & $97 \%$ & $80 \%$ \\
\hline Gram negative cocci & 29 & 19 & 24 & 26 & $58 \%$ & $45 \%$ \\
\hline Gram positive cocci & 2 & 3 & 6 & 87 & $97 \%$ & $75 \%$ \\
\hline
\end{tabular}

$\mathrm{N}=98$ farm children with samples from the child's room, animal shed and barn included

*Identified Eurotium spp. and their teleomorphs: Aspergillus hollandicus, Aspergillus glaucus, Eurotium amstelodami and Eurotium herbarorium.

microbial concentrations in the farm dwellings were significantly and positively correlated with the concentrations in the corresponding animal sheds and barns.

The fungal patterns of non-exposed and exposed dwellings were very similar and characterised by the dominant presence of Penicillium spp., whereas the microflora from the farm dwellings were more similar to the animal shed microflora with Eurotium spp., other Aspergillus spp., Penicillium spp., Cladosporium spp. and Gram positive cocci identified as the dominant groups of microorganisms. Similarities were also found between the bacterial patterns of farm dwellings, animal sheds and barns, and bacterial contamination of non-exposed dwellings was very low compared to that of farm dwellings.

The similarity of the results between animal sheds, barns and farm dwellings is also corroborated by the findings presented in table 3 which show that in a majority of the farm dwellings (58\% to $100 \%$ depending on the microorganism), a positive sample for a given microorganism in the dwelling corresponded to a positive sample in the animal shed or barn.

As shown in table 4, the concentrations of different microorganisms were lower in farm dwellings compared to animal sheds and barns, with ratios for the arithmetic mean varying from 1:6 (Penicillium spp.) to 1:64 (unidentified Eurotium spp.) for fungi, and from 1:11 (mesophilic actinomycetes) to 1:171 (Gram negative rods) for bacteria.

\section{DISCUSSION}

Relationships between the presence of fungi in indoor and outdoor air have been studied previously, and the authors found that outdoor factors may influence the presence of viable mould in indoor environments. ${ }^{21}$ We sought to describe the association between the patterns and levels of viable microorganisms on the farm and in the indoor environment of children by performing a large and extensive environmental study. The similarities in species found in farm dwellings and barns strongly suggest that microorganisms are transported from animal sheds and barns into farm dwellings. Indeed, there is a marked tendency towards an increased number of microbial species and higher levels in farm dwellings compared to rural dwellings. Moreover, this strong indication of transport or flow from barns and animal sheds into dwellings clearly modifies the overall composition of airborne microflora in children's bedrooms. While the bedroom indoor environment of non-exposed children is characterised by a predominance of Penicillium spp., as previously reported, ${ }^{22} 23$ other fungi such as Aspergillus glaucus and its teleomorph

Table 4 Arithmetic means (in $10^{3} \mathrm{CFU} / \mathrm{m}^{2}$ ) and ratio of arithmetic mean of level of microorganisms found in animal sheds and farm dwellings

\begin{tabular}{|c|c|c|c|}
\hline & \multicolumn{2}{|c|}{$\begin{array}{l}\text { Arithmetic means } \\
\left(10^{3} \mathrm{CFU} / \mathrm{m}^{2}\right)\end{array}$} & \multirow{2}{*}{$\begin{array}{l}\text { Arithmetic mean } \\
\text { ratio (animal shed/ } \\
\text { farm dwelling) }\end{array}$} \\
\hline & $\begin{array}{l}\text { Animal shed } \\
(\mathrm{N}=111)\end{array}$ & $\begin{array}{l}\text { Farm dwelling } \\
(N=144)\end{array}$ & \\
\hline Absidia spp. & 835 & 32 & 26 \\
\hline Other Mucorales spp. & 145 & 14 & 10 \\
\hline Aspergillus fumigatus & 1055 & 59 & 18 \\
\hline Identified Eurotium spp.* & 4012 & 177 & 23 \\
\hline Other Eurotium spp. & 3005 & 47 & 64 \\
\hline Other Aspergillus spp. & 1724 & 75 & 23 \\
\hline Alternaria spp. & 75 & 4 & 19 \\
\hline Cladosporium spp. & 2183 & 51 & 43 \\
\hline Penicillium spp. & 639 & 109 & 6 \\
\hline Scopulariopsis sp. & 817 & 13 & 63 \\
\hline Wallemia sebi & 1411 & 54 & 26 \\
\hline Yeast & 1964 & 31 & 63 \\
\hline Other fungi & 715 & 31 & 23 \\
\hline Mesophilic Actinomycetaceae & 6994 & 624 & 11 \\
\hline Thermophilic Actinomycetaceae & 1073 & 66 & 16 \\
\hline Gram negative rods & 173551 & 1013 & 171 \\
\hline Gram positive rods & 279564 & 3270 & 85 \\
\hline Gram negative cocci & 15733 & $431 \dagger$ & 37 \\
\hline Gram positive cocci & 388932 & 6334 & 61 \\
\hline
\end{tabular}

Arithmetic mean ratio is the animal shed mean/farm dwelling mean.

*Identified Eurotium spp. and their teleomorphs: Aspergillus hollandicus, Aspergillus glaucus, Eurotium amstelodami and Eurotium herbarorium.

†One missing value. 
Eurotium amstelodami are also common in farm dwellings. A glaucus is commonly present on farms, especially when hay is distributed to cattle. ${ }^{24-26}$ Other fungal species observed in the farm children's bedroom, such as Absidia spp. and Wallemia sebi, and bacteria such as actinomycetes species, have also been frequently detected in the farm environment ${ }^{11} 27$ and are suspected of being involved in farmer's lung diseases. Moreover, our study showed that for numerous taxa, the concentrations of microorganisms in animal sheds and farm dwellings are positively and significantly correlated, corroborating the hypothesis of a noticeable transfer from the animal shed to the farm dwelling. For actinomycetes and most of the fungal groups, the ratio between arithmetic mean exposures in the dwelling compared to the animal shed is between 1:10 and 1:40. For these microorganisms, it can be extrapolated that when a child has spent $10-40 \mathrm{~h}$ in his or her bedroom, he or she has been in contact with the same number of microorganisms as if he or she had stayed $1 \mathrm{~h}$ in the animal shed. Similarly, bacterial contamination of the bedroom seems influenced by the environment in the animal sheds and barns. This may be due to the propensity of fungal and actinomycetes spores to be easily disseminated in the atmosphere ${ }^{12}$ and carried into dwellings on the hands, clothes or shoes of farmers and their children. ${ }^{13} 2829$

The findings for Penicillium spp. were somewhat different. On the one hand, the low arithmetic mean ratio between the air in farm dwellings and the air in animal sheds, and the positive correlation between the numbers of colonies found in these two locations, suggest that the indoor air in a farm dwelling is contaminated by Penicillium spp. spores originating from the farm. On the other hand, Penicillium species were also the predominant fungal flora in non-farming dwellings, which is concordant with previous studies showing that Penicillium species are among the most typical fungi found in the indoor air of homes. ${ }^{12} 3031$ Apart from the farm environment, there are likely to be other sources of Penicillium species, as highlighted by studies on mould contamination in indoor air. ${ }^{22}$ 32-34 More detailed identification of Penicillium species would have been of interest to determine if the patterns of individual species found in farm dwellings and nonexposed dwellings are different. However, the identification of Penicillium species is particularly difficult even in highly specialised laboratories, as further studies combining molecular, biochemical and physiological approaches are required.

In this study we focused on bacteria and fungi that were easily obtained using standard culture media. Furthermore, we targeted mesophilic and thermophilic fungi and actinomycetes because of their propensity to replicate in indoor environments. ${ }^{35}$ We acknowledge that these microorganisms represent only a small fraction of all airborne microorganisms because numerous bacteria and fungi are difficult or even impossible to culture. $^{35}$ Other approaches such as microscopy or DNA cloning, ${ }^{36}$ that bypass the culturing step, could also be used to assess the microbial diversity in farm dwellings. However, such non-culture based methods, especially the biomolecular approaches, are expensive and difficult to apply to large environmental studies with large series of samples. Both approaches are however complementary and one is not necessarily superior to the other. Nonetheless, the microbial analyses in this study appear to be relevant, since in a separate analysis we have shown that increased diversity of viable microorganisms enhances the protective effect conferred by animal shed fungal and bacterial flora on childhood asthma and atopy. ${ }^{14}$

In conclusion, this study is an important step in the understanding of microbial exposure in farm dwellings because it provides data suggesting transport of microbial species between animal sheds and farm dwellings. This transport clearly determines children's exposure to microorganisms, as it modifies the composition of airborne microflora in the children's bedrooms.

Acknowledgements We thank Dr Wulf Thierfelder and Michael Thamm from the Robert-Koch-Institute, Berlin, Germany for their cooperation and measurements of total and specific lgE that were used in the definition of atopic subjects.

Funding This work was supported by the European Commission as part of GABRIEL (a multidisciplinary study to identify the genetic and environmental causes of asthma in the European Community), contract number 018996 under the FP6-LIFESCIHEALTH Integrated Program LSH-2004-1.2.5-1.

Competing interest None.

Provenance and peer review Not commissioned; externally peer reviewed.

\section{REFERENCES}

1. Braun-Fahrlander C, Gassner M, Grize L, et al. Prevalence of hay fever and allergic sensitization in farmer's children and their peers living in the same rural community. SCARPOL team. Swiss Study on Childhood Allergy and Respiratory Symptoms with Respect to Air Pollution. Clin Exp Allergy 1999;29:28-34

2. Ernst $\mathbf{P}$, Cormier $\mathbf{Y}$. Relative scarcity of asthma and atopy among rural adolescents raised on a farm. Am J Respir Crit Care Med 2000;161:1563-6.

3. Kilpelainen $\mathbf{M}$, Terho E0, Helenius $\mathrm{H}$, et al. Farm environment in childhood prevents the development of allergies. Clin Exp Allergy 2000;30:201-8.

4. Klintberg B, Berglund N, Lilja G, et al. Fewer allergic respiratory disorders among farmers' children in a closed birth cohort from Sweden. Eur Respir J 2001:17:1151-7.

5. Riedler J, Eder W, Oberfeld G, et al. Austrian children living on a farm have less hay fever, asthma and allergic sensitization. Clin Exp Allergy 2000;30:194-200.

6. Von Ehrenstein OS, Von Mutius E, Illi S, et al. Reduced risk of hay fever and asthma among children of farmers. Clin Exp Allergy 2000;30:187-93.

7. Leynaert B, Neukirch C, Jarvis D, et al. Does living on a farm during childhood protect against asthma, allergic rhinitis, and atopy in adulthood? Am J Respir Crit Care Med 2001;164:1829-34.

8. American Thoracic Society MSoAIA. Respiratory health hazards in agriculture. Am J Respir Crit Care Med 1998;158:S1-76.

9. Hanhela R, Louhelainen K, Pasanen AL. Prevalence of microfungi in Finnish cow barns and some aspects of the occurrence of Wallemia sebi and Fusaria. Scand $J$ Work Environ Health 1995;21:223-8.

10. Lange L, Thorne P, Kullman GJ. Determinants of culturable bioaerosol concentration in dairy barn. Ann Agric Environ Med 1997:4:187-94.

11. Reboux G, Piarroux R, Mauny F, et al. Role of molds in farmer's lung disease in Eastern France. Am J Respir Crit Care Med 2001;163:1534-9.

12. Pasanen $\mathbf{A L}$, Kalliokoski $\mathrm{P}$, Pasanen $\mathrm{P}$, et al. Fungi carried from farmers' work into farm homes. Am Ind Hyg Assoc J 1989;50:631-3.

13. Lis D0, Mainelis G, Gorny RL. Microbial air contamination in farmhouses-quantitative aspects. Clean 2008;36:551-5

14. Ege M, Mayer M, Normand AC, et al. Exposure to environmental microorganisms and childhood asthma. N Engl J Med 2011;364:701-9.

15. Normand AC, Vacheyrou M, Sudre B, et al. Assessment of dust sampling methods for the study of cultivable-microorganism exposure in stables. App/ Environ Microbiol 2009; 75:7617-23.

16. Noss I, Wouters IM, Visser M, et al. Evaluation of a low-cost electrostatic dust fall collector for indoor air endotoxin exposure assessment. Appl Environ Microbiol 2008;74:5621-7

17. Amner W, Edwards C, McCarthy AJ. Improved medium for recovery and enumeration of the farmer's lung organism, Saccharomonospora viridis. Appl Environ Microbiol 1989;55:2669-74.

18. de Hoog GS, Guarro J, Gené J, et al. Atlas of Clinical Fungi. 2nd edn. Reus, Spain Centraalbureau voor Schimmelcultures. Utrecht, The Netherlands / Universitat Rovira I Virgili, 2000:1-1007

19. Roussel S, Reboux G, Dalphin JC, et al. Farmer's lung disease and microbiological composition of hay: a case-control study. Mycopathologia 2005;160 273-9.

20. Verhoeff AP, Burge HA. Health risk assessment of fungi in home environments. Ann Allergy Asthma Immunol 1997;78:544-54; quiz 555-6.

21. Verhoeff AP, van Wijnen JH, Brunekreef $B$, et al. Presence of viable mould propagules in indoor air in relation to house damp and outdoor air. Allergy 1992:47:83-91.

22. Reboux G, Bellanger $A P$, Roussel $S$, et al. Indoor mold concentration in Eastern France. Indoor air 2009:19:446-53.

23. Rosas I, Calderon C, Ulloa M, et al. Abundance of airborne Penicillium CFU in relation to urbanization in Mexico City. Appl Environ Microbiol 1993;59:2648-52.

24. Kotimaa MH, Terho EO, Husman K. Airborne moulds and actinomycetes in work environment of farmers. Eur J Respir Dis Supp/ 1987;152:91-100.

25. Kotimaa MH, Oksanen L, Koskela P. Feeding and bedding materials as sources of microbial exposure on dairy farms. Scand J Work Environ Health 1991;17:117-22.

26. Reboux G, Reiman M, Roussel S, et al. Impact of agricultural practices on microbiology of hay, silage and flour on Finnish and French farms. Ann Agric Environ Med 2006;13:267-73. 
27. Roussel S, Reboux G, Dalphin JC, et al. Microbiological evolution of hay and relapse in patients with farmer's lung. Occup Environ Med 2004;61:e3.

28. Waser M, Schierl R, von Mutius $E$, et al. Determinants of endotoxin levels in living environments of farmers' children and their peers from rural areas. Clin Exp Allergy 2004;34:389-97.

29. Korthals M, Ege MJ, Tebbe CC, et al. Application of PCR-SSCP for molecular epidemiological studies on the exposure of farm children to bacteria in environmental dust. J Microbiol Methods 2008;73:49-56.

30. Hyvarinen A, Reponen T, Husman T, et al. Comparison of the indoor air quality in mould damaged and reference buildings in a subarctic climate. Cent Eur J Public Health 2001;:9:133-9.

31. Ren P, Jankun TM, Leaderer BP. Comparisons of seasonal fungal prevalence in indoor and outdoor air and in house dusts of dwellings in one Northeast American county. J Expo Anal Environ Epidemiol 1999:9:560-8.
32. Roussel S, Reboux G, Bellanger AP, et al. Characteristics of dwellings contaminated by moulds. J Environ Monit 2008;10:724-9.

33. Gorny RL, Dutkiewicz J. Bacterial and fungal aerosols in indoor environment in Central and Eastern European countries. Ann Agric Environ Med 2002;9 17-23.

34. Pietarinen VM, Rintala $\mathrm{H}$, Hyvarinen $\mathrm{A}$, et al. Quantitative PCR analysis of fungi and bacteria in building materials and comparison to culture-based analysis. $J$ Environ Monit 2008;10:655-63.

35. Eduard W, Heederik D. Methods for quantitative assessment of airborne levels of noninfectious microorganisms in highly contaminated work environments. Am Ind Hyg Assoc J 1998;59:113-27.

36. Pakarinen J, Hyvarinen A, Salkinoja-Salonen M, et al. Predominance of Grampositive bacteria in house dust in the low-allergy risk Russian Karelia. Environ Microbiol 2008:10:3317-25. 


\section{Airborne cultivable microflora and microbial transfer in farm buildings and rural dwellings}

Anne-Cécile Normand, Bertrand Sudre, Mallory Vacheyrou, Martin Depner, Inge M Wouters, Ilka Noss, Dick Heederik, Anne Hyvärinen, Jon Genuneit, Charlotte Braun-Fahrländer, Erika von Mutius, Renaud Piarroux and the GABRIEL-A Study Group

Occup Environ Med 2011 68: 849-855 originally published online March 24, 2011

doi: 10.1136/oem.2010.061879

Updated information and services can be found at:

http://oem.bmj.com/content/68/11/849

These include:

References This article cites 35 articles, 6 of which you can access for free at: http://oem.bmj.com/content/68/11/849\#BIBL

Email alerting Receive free email alerts when new articles cite this article. Sign up in the service box at the top right corner of the online article.

\section{Notes}

To request permissions go to:

http://group.bmj.com/group/rights-licensing/permissions

To order reprints go to:

http://journals.bmj.com/cgi/reprintform

To subscribe to BMJ go to:

http://group.bmj.com/subscribe/ 